\title{
Long-Term and Ontogenetic Patterns of Heavy Metal Contamination in Lake Baikal Seals (Pusa sibirica)
}

\author{
Ted Ozersky, ${ }^{*}$, , ${ }_{\odot}$ Mikhail V. Pastukhov, ${ }^{\ddagger}$ Amanda E. Poste, ${ }^{\S}$ Xiu Y. Deng, ${ }^{\|}$and Marianne V. Moore ${ }^{\|}$ \\ ${ }^{\dagger}$ Large Lakes Observatory, University of Minnesota Duluth, Duluth, Minnesota 55812, United States \\ ${ }^{*}$ Vinogradov Institute of Geochemistry, Siberian Branch of the Russian Academy of Sciences, Irkutsk, Russia \\ ${ }^{\S}$ Norwegian Institute for Water Research, Oslo, Norway \\ "Department of Biological Sciences, Wellesley College, Wellesley, Massachusetts 02481, United States
}

\section{Supporting Information}

ABSTRACT: Little is known about the history of heavy metal pollution of Russia's Lake Baikal, one of the world's largest lakes and a home to numerous endemic species, including the Baikal Seal, Pusa sibirica. We investigated the history of heavy metal (V, Cu, Zn, Cd, Hg, Tl, Pb, U) pollution in Lake Baikal seals over the past 8 decades. $\mathrm{C}$ and $\mathrm{N}$ stable isotope analysis (SIA) and laser-ablation ICP-MS of seal teeth were used to examine changes in feeding ecology, heavy metal levels associated with life history events and long-term variation in metal exposure. SIA did not suggest large changes in the feeding ecology of Baikal seals over the past 80 years. LA-ICPMS analyses revealed element-specific ontogenetic variability in

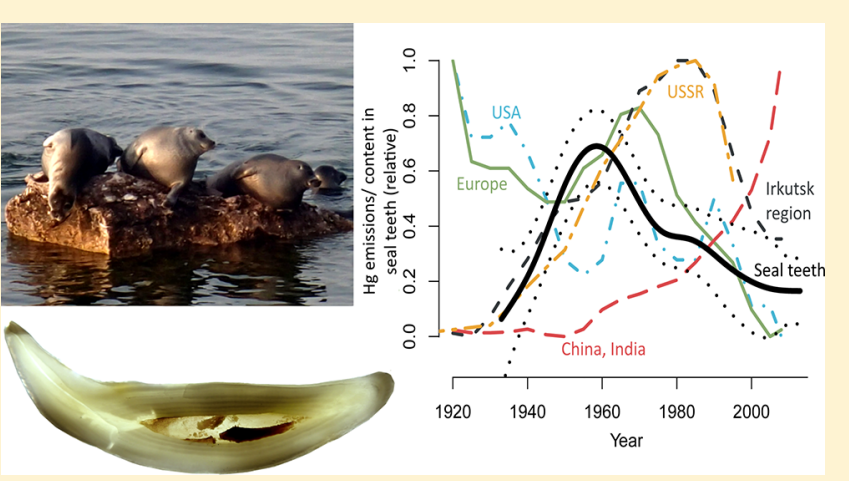
metal concentrations, likely related to maternal transfer, changes in food sources and starvation. $\mathrm{Hg}$ and $\mathrm{Cd}$ levels in seals varied significantly across the time series, with concentrations peaking in the 1960s - 1970s but then declining to contemporary levels similar to those observed in the 1930s and 1940s. Trends in atmospheric emissions of $\mathrm{Hg}$ suggest that local sources as well as emissions from eastern Russia and Europe may be important contributors of $\mathrm{Hg}$ to Lake Baikal and that, despite the size of Lake Baikal, its food web appears to respond rapidly to changing inputs of contaminants.

\section{INTRODUCTION}

Fossil fuel combustion, mining, metallurgy, and manufacturing have significantly increased the amount of toxic heavy metals circulating in the biosphere since the industrial revolution. ${ }^{1-3}$ In many places, environmental concentrations of some metals are high enough to represent risks to wildlife and human health. ${ }^{4,5}$ Although areas close to sources of heavy metal emissions tend to be more contaminated, long-range atmospheric transport can result in elevated levels of some metals even in remote regions. ${ }^{6-9}$ Metals that potentially biomagnify (e.g., $\mathrm{Hg}, \mathrm{Cd}$ ) are of special concern, since they can reach high concentrations in upper trophic levels and impact animals that are ecologically important or are consumed by humans.

Managing risks associated with metal pollution requires understanding the sources and behavior of these elements, as well as how their concentrations vary through time in relation to environmental change. Sediment and ice cores ${ }^{6,9-13}$ provide valuable information about inputs and sources of heavy metals into specific areas. Other long-term recorders of heavy metal contamination are hard animal tissues such as bivalve shells, hair, feathers, or teeth, which have been used to describe trends in heavy metal concentrations in clams, birds, polar bears, beluga whales, pinnipeds, and humans. ${ }^{14-18}$ Analysis of animal tissues can illuminate a different facet of long-term trends than that revealed by "passive" recorders such as ice cores, because concentrations in animal tissues reflect not only concentrations in the environment, but also patterns in food web transfer and animal life history. ${ }^{19,20}$ Importantly, and unlike data from "passive records", potential toxicological impacts can be deduced from concentrations in archival tissue when such concentrations are linked directly to those in soft tissue and to toxicological thresholds. ${ }^{21}$ Information about inputs to ecosystems may also be gleaned from animal tissue records if life history and food web factors (such as age and trophic position) are considered. ${ }^{17,20,21}$

In Russia's Lake Baikal, the top consumer is the Baikal seal (Pusa sibirica), the world's only true freshwater seal. Baikal seals are culturally and economically important in the Baikal region, and have long been hunted for furs and food by humans living on the shores of the lake. ${ }^{22}$ The earliest measurements of heavy

Received: February 23, 2017

Revised: August 7, 2017

Accepted: August 10, 2017

Published: August 10, 2017 
metal concentrations in Baikal seals (or any other compartment of the Lake Baikal food web) were carried out in the early $1990 \mathrm{~s}^{23}$ and appear to have remained relatively stable since then at levels that do not pose risks to the seals or their human consumers. $^{24,25}$ It is unknown, however, how recent metal concentrations in Baikal seals and the Lake Baikal food web in general compare with historic values throughout the 20th century, a period marked by global and regional environmental change. Aside from helping to reconstruct the pollution history in Lake Baikal, examination of past trends in metal contamination may help determine whether the food web of this large and remote lake is sensitive to potential future changes in heavy metal inputs.

Various anthropogenic sources could have contributed heavy metals to Lake Baikal throughout the 20th century. Regional sources include gold mining in the watershed (beginning in the 19th century), combustion of fossil fuels and emissions from industry. Atmospheric transport from industrial centers in the Eastern USSR, Europe and further afield is another potential pathway for transport of mobile elements like $\mathrm{Hg}, \mathrm{Cd}, \mathrm{Pb}$, and $\mathrm{Tl}^{7-14}$ Understanding historical patterns and sources of metal contamination to Lake Baikal is also important in the context of recent accelerated environmental change in the region. Increasing frequency of forest fires in Siberia, ${ }^{26}$ continuing increases in $\mathrm{Hg}$ emissions in China and India, ${ }^{9}$ intensifying mining along tributaries of Lake Baikal in Mongolia, ${ }^{27}$ eutrophication in Lake Baikal $^{28}$ and climate change ${ }^{29}$ can all potentially change inputs of metals to the lake or their transfer through the food web.

Our primary goal was to determine the recent history of metal pollution in Lake Baikal's top predator. We used an archival collection of Baikal seal teeth together with $\delta^{13} \mathrm{C}$ and $\delta^{15} \mathrm{~N}$ stable isotope analysis (SIA) and laser ablation ICP-MS to answer three questions: (1) Did the trophic level or food sources of the Baikal seals change over the last 80 years? (2) Are there ontogenetic and seasonal patterns in the concentrations of $\mathrm{V}, \mathrm{Zn}, \mathrm{Cu}, \mathrm{Cd}, \mathrm{Hg}, \mathrm{Pb}, \mathrm{Tl}$, and $\mathrm{U}$ in Baikal seal teeth? (3) Did levels of these metals change over the last 80 years in Baikal seals? We address these questions in the context of documented environmental change in the Lake Baikal region, the life history of the Baikal seal and emission trends in potential source areas of pollution.

\section{MATERIALS AND METHODS}

Study Site and Background. Located in central Siberia, Lake Baikal-the deepest and oldest lake in the world-is host to hundreds of endemic species, including the Lake Baikal seal (Supporting Information Figure S1). Baikal seals are born in spring in ice caves, feed on milk for the first 2-2.5 months of their life, and then transition to an adult diet, composed primarily of the endemic sculpins Comephorus and Cottocomephorus spp. ${ }^{30}$ Baikal seals actively feed throughout most of the year, but food intake is lower in winter and almost stops during a 4-6 week period of starvation in late spring associated with moulting and sun basking, during which seals can lose almost all their fat reserves. ${ }^{31}$ Baikal seals are long-lived, with individuals as old as 56 yrs being recorded. ${ }^{30}$ As in many mammals, life history events such as birth, suckling, active feeding and moulting are "recorded" in teeth of seals as alternating bands of opaque and translucent dentine (Figure 1). Dentine bands are laid down from the "outside in", so prenatal dentine is laid down closest to the outside of the tooth (right beneath the enamel and cementum), and subsequent layers are

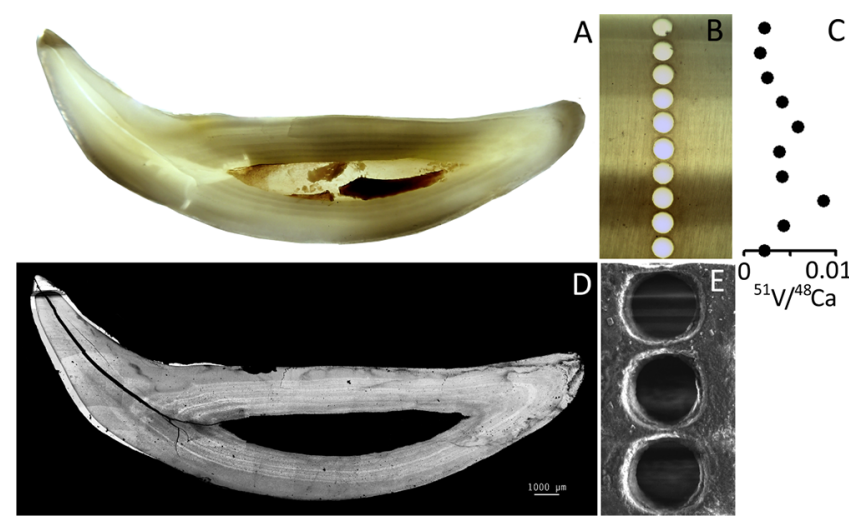

Figure 1. Dentine layers in Baikal seal canines. (A) Longitudinal section of a canine tooth (5-year-old female) with dried pulp material in the center and a (B) close-up of ablation craters under a light microscope with $(\mathrm{C}){ }^{51} \mathrm{~V} /{ }^{48} \mathrm{Ca}$ count-per-second ratios for craters shown in (B). (D) A longitudinal section of a canine tooth under an electron microprobe and the (E) $100 \mu \mathrm{m}$ diameter craters created with ablation laser.

formed on the "inside", closer to the pulp cavity which is in the center of the tooth. Each dentine layer subsequently deposited is thinner than the preceding one and when a seal reaches approximately 10 years of age the layers become difficult to distinguish; at age 20-25 years, the pulp cavity becomes completely occluded with dentine. ${ }^{30,31}$ Because dentine is not remodeled after formation, the dentine bands laid down during the early years of life represent a reliable age-specific recorder of stable isotope values and metal exposure. ${ }^{32-36}$ For example, prenatal and first year-of-life dentine laid down by a 30 -year old animal harvested in 1960 would record SI values and metal levels in 1930. Thus, knowing the year of capture, age of the animal and identity of the dentine band, we can go back to the first years of life of each seal. Age of seals was determined by counting cementum bands ${ }^{30,31}$ which, unlike dentine, grow from the "inside out" and remain consistently thick throughout life, but are too thin for sampling at subannual resolution by LA-ICP-MS or for obtaining material for SIA. Subannual sampling of the opaque and translucent bands of dentine with LA-ICP-MS also allowed us to quantify metals during normal growth (translucent dentine) and periods of nutritional stress such as winter months and moulting periods (opaque dentine).

Sample Collection and Processing. Seals were collected between 1965 and 2013. Between 1965 and 1989, seals were collected mostly in central Baikal by Russian researchers working with commercial seal hunters, retaining skulls and teeth for morphometric analyses. Sampling was more intensive in some years than others; of the seals used in this study 19, 28, and 14 were collected in the 1960s, 1970s and 1980s, respectively. In 2013, 22 seals were collected and dissected in the field in southern and central L. Baikal under scientificcollection permit No. 032013031058 issued to M. Pastukhov by the Russian Federal Fisheries Agency. Upper canines were removed from seal skulls and cleaned to remove external debris. Teeth were mounted on wooden blocks with epoxy resin (Epofix, Struers) and sliced longitudinally on a low speed IsoMet saw (Buehler) with a diamond wafering blade to form two $1 \mathrm{~mm}$ thick slices centered on the tooth midline (Figure 1). One slice was used for $\delta^{13} \mathrm{C}$ and $\delta^{15} \mathrm{~N}$ SIA, the other for LAICP-MS analysis. 
$\delta^{13} \mathrm{C}$ and $\delta^{15} \mathrm{~N}$ SIA. Dentine for $\delta^{13} \mathrm{C}$ and $\delta^{15} \mathrm{~N}$ SIA was removed from tooth slices using a Dremel tool (Robert Bosch $\mathrm{GmbH}$ ) with a fine, carbide-tipped dental bit. Approximately 20 $\mathrm{mg}$ of dentine were drilled separately from the prenatal and first translucent dentine (corresponding to the first period of independent feeding) layers of teeth from 56 seals. We recovered dentine from only these two layers because subsequent layers were typically too narrow to sample with our approach. Dentine was decarbonated using $10 \% \mathrm{HCl}$, centrifuged and washed, leaving behind mostly collagen. ${ }^{35,36}$ In addition to dentine collagen, soft tissue samples collected from the pulp cavities (Figure 1A) of teeth from 51 seals were analyzed for SI. Pulp cavity material was comprised mainly of dried blood and blood vessels, and its SI values should represent those over the last few months of the life of the animal before capture. $\% \mathrm{C}$ and $\% \mathrm{~N}$ values were used to evaluate whether tissue spoilage and changes to $\delta^{13} \mathrm{C}$ and $\delta^{15} \mathrm{~N}$ SI values had occurred during sample storage. ${ }^{34}$ Samples with unusual $\% \mathrm{C}$ and $\% \mathrm{~N}$ (>3 SD from mean) were excluded from analysis; of the 192 samples analyzed 37 were excluded on this basis. SIA was performed at the UC Davis Environmental Stable Isotope Lab. Every fifth sample was analyzed in duplicate; differences between duplicate samples ranged up to $0.56 \%$ (average $=0.2 \%$ ) for $\delta^{13} \mathrm{C}$ and $0.67 \%$ (average $=$ $0.37 \%$ ) for $\delta^{15} \mathrm{~N}$. Trends in SI values from seal dentine were compared with published $\delta^{13} \mathrm{C}$ and $\delta^{15} \mathrm{~N}$ SI values ${ }^{37}$ for omul scales (Baikal whitefish, Coregonus autumnalis migratorius), spanning the period between 1947 and 1995. Omul scale SI data were extracted from Figures 3 and 4 of Ogawa et al. ${ }^{37}$ using WebPlotDigitizer. ${ }^{38}$ All seal and omul $\delta^{13} \mathrm{C}$ values were Suess-corrected ${ }^{39}$ to account for increased ${ }^{13} \mathrm{C}$ in the atmosphere due to fossil fuel combustion; 1966 was used as the "baseline" for corrections.

LA-ICP-MS Analysis. Tooth sections for LA-ICP-MS analysis were cleaned by rinsing in ultrapure deionized water and trace metal clean 5\% nitric acid. Analysis was conducted at the Woods Hole Oceanographic Institution Plasma Mass Spectrometry Facility on a high-resolution magnetic sector Element2 ICP-MS (Thermo Fisher Scientific) coupled to a 193 $\mathrm{nm}$ excimer laser ablation system (Electro Scientific Industries). LA-ICP-MS run parameters are shown in Table S1. Between 2 and 10 spots per tooth (depending on animal age and tooth thickness; Figure 1) were analyzed, starting from prenatal dentine and moving toward the pulp cavity. In total, teeth of 45 seals were analyzed. Analysis targeted ${ }^{51} \mathrm{~V},{ }^{63} \mathrm{Cu},{ }^{64} \mathrm{Zn},{ }^{114} \mathrm{Cd}$, ${ }^{202} \mathrm{Hg},{ }^{205} \mathrm{Tl},{ }^{208} \mathrm{~Pb},{ }^{238} \mathrm{U}$. These metals were selected because of their toxicity and association with anthropogenic pollution. ${ }^{48} \mathrm{Ca}$ was used as an internal standard, ${ }^{14,40}$ with metal concentrations expressed as a ratio of counts-per-second relative to ${ }^{48} \mathrm{Ca}$. Concentrations of ${ }^{48} \mathrm{Ca}$ (as CPS) were consistent in different layers of teeth, varying minimally within and across teeth compared to concentrations of target metals. NIST612 glass was used as an external standard. Instrument blanks (carrier gas and 2\% $\mathrm{HNO}_{3}$ ) and the NIST612 standard were analyzed at the start and end of a run for each tooth. On average, element $/{ }^{48} \mathrm{Ca}$ ratios of duplicate NIST612 analyses (at start and end of each sample run) differed by $2.2 \%, 4.3 \%, 6.9 \%$, $9.6 \%, 23.1 \%, 20.4 \%, 20.4 \%$, and $21.9 \%$ for ${ }^{51} \mathrm{~V},{ }^{63} \mathrm{Cu},{ }^{64} \mathrm{Zn}$, ${ }^{114} \mathrm{Cd},{ }^{202} \mathrm{Hg},{ }^{205} \mathrm{Tl},{ }^{208} \mathrm{~Pb}$, and ${ }^{238} \mathrm{U}$, respectively. Drift in blanks and standards was accounted for by assuming linear change during analysis of each tooth. ${ }^{14}$ Final results were expressed as the ratio of counts-per-second (CPS) for each element to ${ }^{48} \mathrm{Ca}$, standardized (relative) to NIST612 CPS. While this approach does not allow for determination of absolute concentrations of metals in teeth, it ensures that results are consistently expressed relative to a homogeneous standard, allowing comparison of metal concentrations across samples. Results for spots with high variability in metal concentrations $(>10 \%$ relative standard deviation in CPS) during ablation were excluded from analysis on the assumption that the laser encountered another dentine layer or impurities during ablation; less than $3 \%$ of observations were excluded in this way. Ablated tooth sections were examined under an optical transmission microscope with polarized light and ablated spots were assigned to dentine layers. Data from spots that obviously overlapped layers (e.g., fourth spot from top in Figure 1B) were not included in the final analysis; multiple samples from the same layer (e.g., fifth and sixth spot from top in Figure 1B) were aggregated by averaging.

Data Analysis. $\delta^{13} \mathrm{C}$ and $\delta^{15} \mathrm{~N}$ Values. GAMMs (generalized additive mixed models) were used to model trends in $\delta^{13} \mathrm{C}$ and $\delta^{15} \mathrm{~N}$ stable isotope ratios in seal tooth pulp and dentine using the mgcv package ${ }^{41}$ in the $\mathrm{R}$ statistical computing environment. ${ }^{42}$ GAMMs allow fitting of nonlinear splines while incorporating random effects and nesting. ${ }^{43}$ Models were parametrized to fit smoothers to $\delta^{13} \mathrm{C}$ and $\delta^{15} \mathrm{~N}$ values for all seal tissues (prenatal dentine, translucent dentine, pulp tissue) with year of sample (year corresponding to the formation of a dentine layer or year of animal death for pulp tissue), tissue type, gender and age-at-death as fixed predictor variables and seal ID as a random variable. Models were simplified by sequentially dropping nonsignificant predictor variables, until all remaining variables contributed significantly to the model $(\alpha$ $=0.05$ ). Diagnostic plots were used to assess the assumptions of normal distribution and homogeneity of variance of residuals; assumptions were met in all cases and no transformations were needed.

Metal Concentrations in Dentine. Repeated-measures, linear mixed-effects ANOVAs, followed by Tukey posthoc tests were used to examine differences in metal concentrations in different dentine layers of teeth to assess ontogenetic and seasonal differences in incorporation of metals into dentine. The repeated-measures, mixed-effects approach was used because different dentine layers are nested within each seal and represent repeated measures for each animal. Analysis was implemented using the nlme ${ }^{44}$ and multcomp ${ }^{45}$ packages in $\mathrm{R}$. To account for potential differences in metal concentrations between seals due to temporal trends and to improve normality and variance of residuals, metal concentrations were standardized for each seal to mean $=0$ and standard deviation $=1$; thus analyses compare relative differences in metal concentrations in different dentine layers. Although up to seven dentine layers were analyzed for some seals, we restricted statistical comparisons to the first five layers, since there were few samples of layers 6 and 7 .

GAMMs were used to examine temporal trends in concentrations of metals across the 80 years covered by our data set. Concentration trends of each metal were modeled separately with year of sample, gender and age $(<1$ year old or $>1$ year old) as fixed independent variables and dentine layer identity (prenatal, first opaque layer, first translucent layer, etc.) and seal ID as random variables, with layers nested within seal ID. Models were simplified as described for SI GAMM models. Absence of temporal autocorrelations was confirmed by plotting autocorrelation function (ACF) values. Metal data 
were normalized to mean $=0$ and standard deviation $=1$ across all seals to improve normality and variance of residuals; assumptions were assessed using diagnostic plots, and were met in all cases.

$\mathrm{Hg}$ Source Attribution. To attempt source attribution of $\mathrm{Hg}$, the most toxic metal to display a significant time trend in the dentine of the Baikal seals, we compiled information about atmospheric $\mathrm{Hg}$ emissions in potential source regions. We compiled data on estimates of atmospheric $\mathrm{Hg}$ emissions from four different regions in the Northern Hemisphere ${ }^{46}$ and coal combustion in the Irkutsk region. ${ }^{47}$ Data were extracted for 5year intervals and normalized on a 0 -to- 1 scale to eliminate differences in units of measurement. These normalized data were plotted with the spline of normalized data for dentine $\mathrm{Hg}$.

\section{RESULTS AND DISCUSSION}

Seal Trophic Position and Energy Sources. GAMM models on combined seal tissues (pulp material and two types of dentine) showed significant differences in $\delta^{13} \mathrm{C}$ between tissue types (pulp tissue was more depleted in ${ }^{13} \mathrm{C}$ than both types of dentine) and a significant overall trend in Suesscorrected $\delta^{13} \mathrm{C}$ values through time, with increase of approximately $1 \%$ o between the 1960 s and the present (Figure $2 \mathrm{~A}, \mathrm{~B}$ ). Increasing $\delta^{13} \mathrm{C}$ values through time could be due to increased rate of planktonic primary production ${ }^{48,49}$ or increased importance of benthic energy sources to the seals. The first explanation is consistent with inferred increases in primary production in Lake Baikal over past decades, ${ }^{29,50}$ and
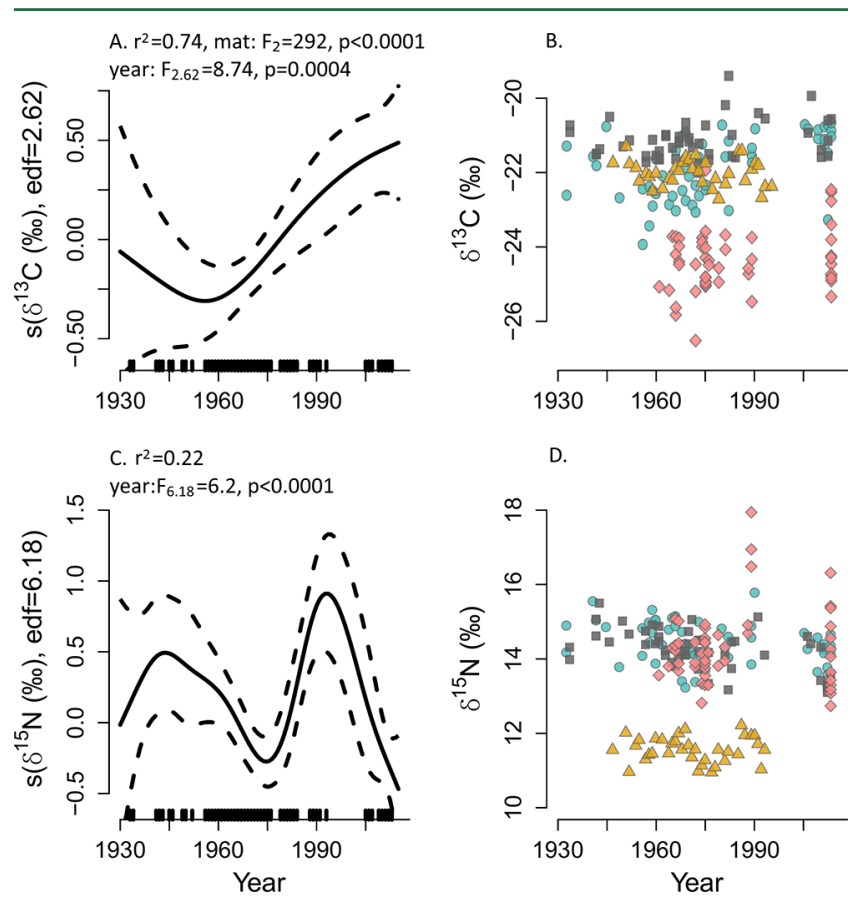

Figure 2. Stable isotopic composition of Baikal seal tissues and omul scales. (A) centered GAMM response function of $\delta^{13} \mathrm{C}$ values for all seal tissues shows a significant time trend and differences between tissue types (mat). (B) $\delta^{13} \mathrm{C}$ values for seal prenatal dentine (blue circle), year 1 translucent dentine (gray square), pulp material (red diamond), and omul scales (orange triangle). (C) centered GAMM response function of $\delta^{15} \mathrm{~N}$ values for seal tissue shows a significant time trend. (D) $\delta^{15} \mathrm{~N}$ values for seal material and omul scales; same symbols as in (B). In (A) and (C) rug plots along $x$-axis show distribution of sample points through time; edf $=$ estimated degrees of freedom. the magnitude of the increase in $\delta^{13} \mathrm{C}$ agrees with published chlorophyll $-\delta^{13} \mathrm{C}$ relationships. ${ }^{48}$ Increased importance of benthic carbon in seal diets would also be consistent with enrichment in $\delta^{13} \mathrm{C},{ }^{51}$ but is less likely. Baikal seals consume mostly golomyanka fish, a strictly pelagic feeder ${ }^{30}$ and it is unlikely that diets of golomyanka changed much over time. In any case, the very modest change in seal $\delta^{13} \mathrm{C}$ values does not indicate major changes to diets.

No significant differences were noted among seal tissue types in $\delta^{15} \mathrm{~N}$ values, but $\delta^{15} \mathrm{~N}$ values showed significant, although not directionally consistent, variation through time (Figure 2C, D). A large "hump" in $\delta^{15} \mathrm{~N}$ values in the late 1980s was mostly driven by samples of pulp tissue from three young seals. Removing these pulp samples did not significantly change the overall shape or significance of the trends. Seal $\delta^{15} \mathrm{~N}$ values were consistently higher than omul scale values, suggesting seals are approximately 1 trophic level above omul, although omul are not an important part of seal diets. ${ }^{30}$ Like in seals, omul $\delta^{15} \mathrm{~N}$ values fluctuated through time, but with no directional trend. The observed fluctuations in $\delta^{15} \mathrm{~N}$ values could be due to changes in the feeding patterns and trophic level of seals and omul ${ }^{52}$ or variation in the sources of $\mathrm{N}$ to primary producers in the system, ${ }^{53}$ but separating these two processes is impossible with available data. In any case, the modest increase in $\delta^{13} \mathrm{C}$ values and the lack of a large variation or consistent directional change in $\delta^{15} \mathrm{~N}$ values do not suggest that the diets of Baikal seals changed much over the last 80 years. This result makes it more likely that temporal trends in dentine metal concentrations (see below) reflect changes in metal inputs into the lake rather than changing food web structure.

Ontogenetic Shifts and Seasonal Patterns of Dentine Metal Concentrations. There were significant variations in metal concentrations in dentine formed in different periods of the lives of Baikal seals, and different metals showed different patterns of variation among dentine layers (Figure 3). Several metals were significantly and strongly correlated with each other when examined across all samples (Spearman's rank correlation test, Figure S2): Hg concentrations were negatively correlated with $\mathrm{V}$, whereas $\mathrm{V}, \mathrm{Pb}$, and $\mathrm{U}$ were positively correlated with each other and negatively correlated with $\mathrm{Zn}$. Interpretation of these patterns is not straightforward because the behavior and tissue-partitioning of metals in organisms is complex and highly element-specific, and because studies on the biological behavior of some metals (e.g., Tl) are rare. Additionally, few studies have examined microspatial variation of metals in human and animal teeth, ${ }^{16,54-57}$ and the causes of these variations are not well-understood at present.

Despite uncertainties about the relationship between soft tissue and dentine metal concentrations, some of the microspatial patterns in metal concentrations that we observed agree with what is known about maternal transfer and ontogenetic changes in metal concentrations in mammals. For example, it is well-known that $\mathrm{Hg}$ levels in neonatal and very young pinnipeds can be high ${ }^{58,39}$ because the placenta does not form an effective barrier to the transfer of $\mathrm{Hg}{ }^{60}$ This agrees with our results, which showed high $\mathrm{Hg}$ levels in prenatal dentine and a decrease with age, and with results from analysis of soft tissues of contemporary Baikal seals. ${ }^{21}$ The behavior of $\mathrm{Tl}$ has not been studied in pinnipeds, but the low levels in prenatal dentine and subsequent increase in our samples may be due to the low permeability of the placenta to Tl (as has been shown for rats ${ }^{61}$ ), followed by $\mathrm{Tl}$ accumulation from food 

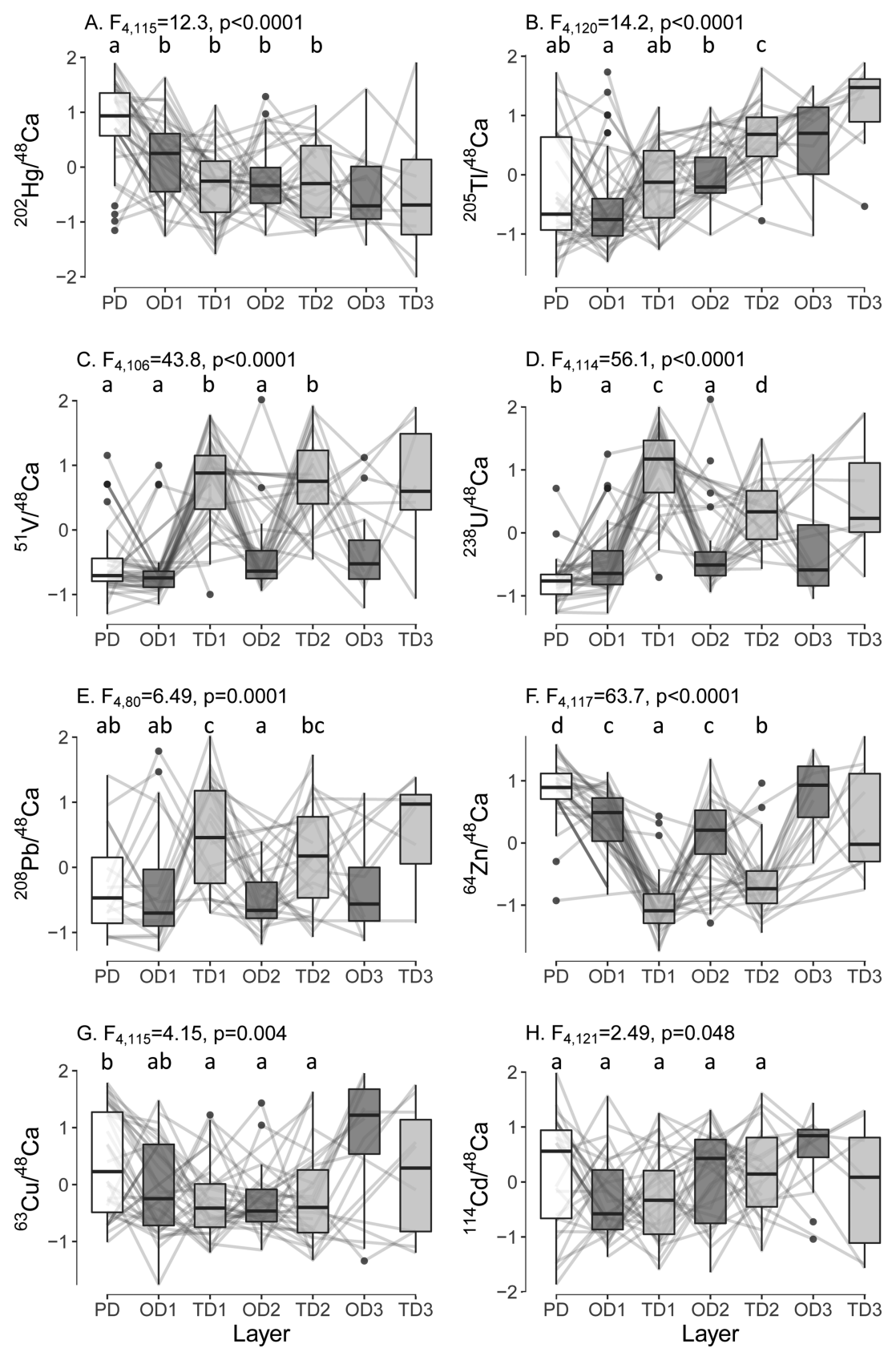

Figure 3. Variation in standardized metal concentrations in different dentine layers of Baikal seal teeth. $X$-axis labels: $\mathrm{PD}=$ prenatal dentine, $\mathrm{OD}=$ opaque dentine, and TD = translucent dentine with numerals denoting year of life in which the dentine layer was formed. Gray "spaghetti" lines represent changes for individual seals. Results of mixed model ANOVAs and Tukey posthoc tests performed on values for the first five layers are shown above each figure. Dentine layers sharing a common letter were not significantly different at the 0.05 level (Tukey post hoc test).

or water after birth. The maternal transfer of $\mathrm{V}, \mathrm{U}$, and $\mathrm{Pb}$ has been well established, but the placenta acts as a partial barrier to these metals and their levels are lower in newborn mammals than in their mothers, ${ }^{60,62,63}$ which may account for relatively low levels of these metals in prenatal and opaque dentine formed early in life in Baikal Seals. Wagemann et al. ${ }^{58}$ observed higher levels of $\mathrm{Zn}$ and $\mathrm{Cu}$ in tissues of seal pups than in tissues of their mothers, attributing it to higher nutritional requirements for these elements by young seals, which may account for the higher levels of $\mathrm{Cu}$ and $\mathrm{Zn}$ we observed in dentine formed early in life. Placental $\mathrm{Cd}$ transfer is not well understood, but appears to be lower than for $\mathrm{Hg}^{60}$ which may account for the lack of difference in $\mathrm{Cd}$ concentrations between prenatal dentine and dentine laid down later in life.
The slow (but not significant) increase in Cd levels in dentine laid down later in life may be due to increased accumulation of this metal from food.

Postnatal seasonal differences in metal concentrations between opaque and translucent dentine may be related to patterns of feeding and starvation by the seals, but less is known about seasonal than early life ontogenetic changes in metal concentrations in marine mammals. Higher concentrations of $\mathrm{V}, \mathrm{Pb}$, and $\mathrm{U}$ in translucent dentine may indicate higher intake and blood levels of these elements during periods of active feeding, but the lack of a similar pattern for other metals argues against this interpretation. Increased concentrations of $\mathrm{Zn}$ in opaque dentine formed during starvation periods are difficult to explain, but may reflect loss of $\mathrm{Zn}$ from catabolized muscles to 

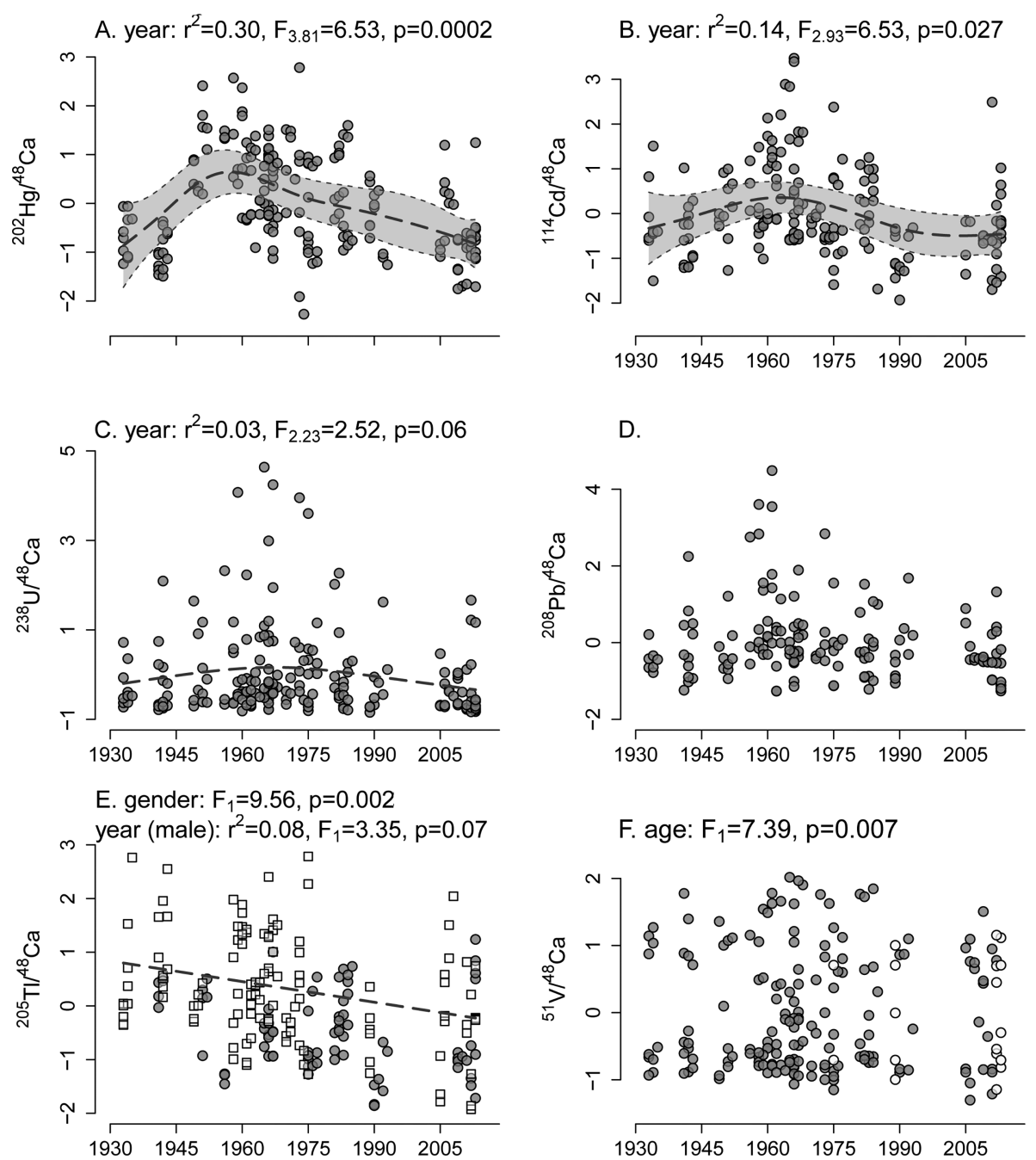

F. age: $F_{1}=7.39, p=0.007$

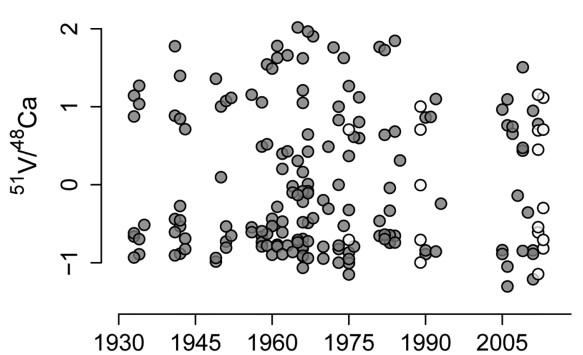

G. age: $F_{1}=38.8, p<0.0001$

H. age: $F_{1}=12.8, p=0.0005$
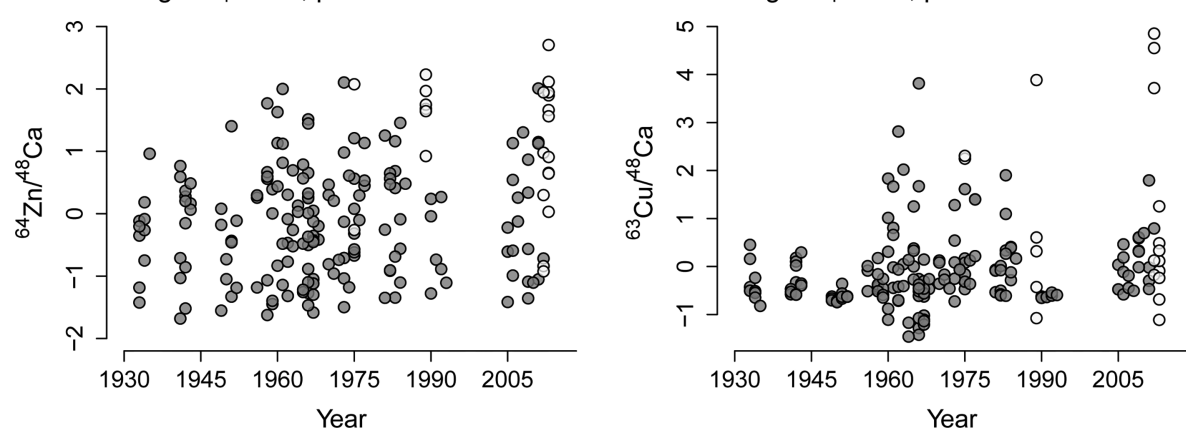

Figure 4. Variation in concentrations of eight different metals in Baikal seal teeth across the 80-year time series. Results of GAMM analyses are shown where a significant effect of an independent variable (i.e., year, age, or gender) was detected. Trendlines with a $95 \%$ prediction interval are shown only where time trends were significant. Filled circles = adult seals, empty circles = juvenile seals. In E: filled circles = female seals, empty squares $=$ male seals.

the blood and subsequent deposition in dentine. Research on starved turkey poults and rats ${ }^{64,65}$ has shown that $\mathrm{Zn}$ levels in many tissues increased during starvation as $\mathrm{Zn}$ from skeletal muscle was remobilized. Copper remobilization in young turkeys during starvation followed similar patterns to $\mathrm{Zn}$, but was less pronounced, ${ }^{65}$ which may explain the lack of a strong seasonal pattern in dentine $\mathrm{Cu}$ levels.

This is the first study to explicitly characterize variation in metal concentrations in the teeth of an aquatic mammal on a subannual time scale, and our findings of metal-specific variation among different dentine layers call for better understanding of the seasonality of metal concentrations in aquatic mammals and of the relationships between soft tissue and dentine metal concentrations. Improved understanding of the relationships between metal concentrations in the body and dentine $^{21}$ would open new possibilities for exploring seasonal and ontogenetic patterns in metal contamination based on tooth samples in mammals. 
Long-Term Trends in Metal Concentrations. We found significant temporal trends for standardized concentrations of $\mathrm{Hg}$ and $\mathrm{Cd}$ in Baikal seal dentine over an 8-decade period (Figure 4A, B). Concentrations of $\mathrm{Hg}$ and $\mathrm{Cd}$ were low in the 1930 s and 1940s, increased in the 1950s to peak concentrations through the 1960s and early 1970s and then decreased and stabilized at levels comparable to those of the 1930s and 1940s. It is interesting to note that $\mathrm{Hg}$ and $\mathrm{Cd}$ are the metals most likely to biomagnify among those examined. ${ }^{66,67}$ Although no significant trends were observed for $\mathrm{U}$ or $\mathrm{Pb}$, their highest concentrations were also observed in the 1960s and 1970s (Figure 4C, D). There were no significant time trends for other metals. However, Tl levels were higher in male than female seals (Figure 4E), with a weak and borderline-significant downward trend through time in males, a pattern that we struggle to explain. Levels of $\mathrm{V}, \mathrm{Zn}$, and $\mathrm{Cu}$ were significantly higher in juvenile than adult seals. As stated earlier, it is well established that $\mathrm{Zn}$ and $\mathrm{Cu}$ levels are higher in juveniles than adult mammals, but we are unsure how to explain the pattern for $\mathrm{V}$.

The trends we observed for $\mathrm{Hg}$ and $\mathrm{Cd}$ are in general agreement with a wide range of studies tracking temporal changes in atmospheric inputs of metals to lake sediments and glacier ice, concentrations in archival animal tissues and inventories of atmospheric emission of metals. ${ }^{9-12,14,17,47,68-71}$ Studies reconstructing metal inputs into glaciers and sediments have documented large increases in atmospheric transport and deposition of many metals associated with coal combustion and metallurgy $(\mathrm{Hg}, \mathrm{Cd}, \mathrm{Zn}$, $\mathrm{Cu}$, and $\mathrm{Tl}$ among others) and of $\mathrm{Pb}$, associated mainly with leaded gasoline use, throughout the first half of the 20th century, including in the Lake Baikal region. ${ }^{10,47}$ As we have shown for Lake Baikal, some regions experienced declines in atmospheric metal inputs starting in the last decades of the 20th century, presumably due to improved pollution controls, reduced use of leaded gasoline and economic forces. ${ }^{6,11-14}$ Studies utilizing archival animal tissues to reconstruct metal inputs into aquatic environments have also often shown increasing concentrations of heavy metals through the 20th century, followed by declines in some locations. For example, $\mathrm{Pb}$ levels in shells of Atlantic clams near the coast of the U.S. closely tracked the rise and eventual decline of U.S. lead emissions from gasoline. ${ }^{14}$ Levels of $\mathrm{Hg}$ in archival collections of bird feathers, polar bear and arctic seal teeth also track changing atmospheric $\mathrm{Hg}$ emissions in potential source regions. ${ }^{15,17,20}$

An interesting question is why we observed temporal changes in levels of some metals associated with fossil fuel combustion $(\mathrm{Hg}, \mathrm{Cd})$, but not others $(\mathrm{V}, \mathrm{Cu}, \mathrm{Zn}, \mathrm{Tl}, \mathrm{Pb}, \mathrm{U})$. One possible explanation is the different susceptibility of metals to volatilization during coal combustion and hence long-range atmospheric transport. For example, $\mathrm{Hg}$ is especially prone to volatilization and hence very long-range transport, ${ }^{72}$ which may mean Baikal receives $\mathrm{Hg}$ from more sources than other elements. The idiosyncratic behavior of different metals in organisms (e.g., $\mathrm{Cu}$ and $\mathrm{Zn}$ are biologically essential elements and may be under stricter physiological than environmental control) may offer another explanation for the lack of concordance in concentration trends of metals associated with fossil fuel emissions.

Emission trends of $\mathrm{Hg}$ and other metals often follow distinct regional trajectories (Figure 5). For example, both the peak and the decrease in atmospheric $\mathrm{Hg}$ emissions in Europe and the

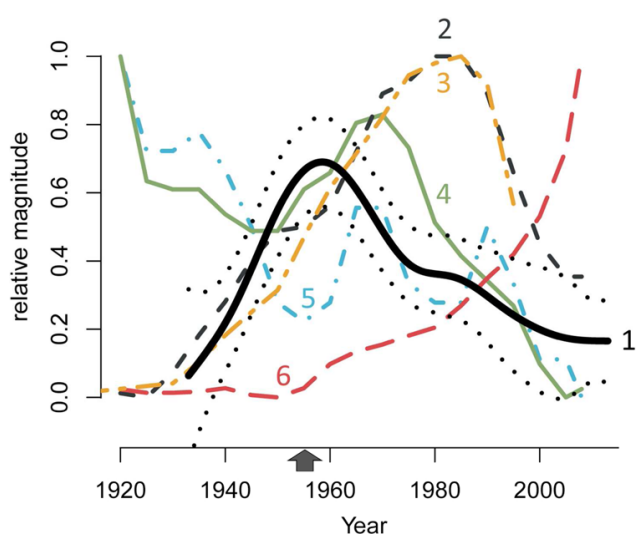

Figure 5. Temporal trends of $\mathrm{Hg}$ in seal teeth (1) bounded by $95 \%$ confidence intervals (black dots), coal power consumption rates in Irkutsk region (2) and estimated atmospheric $\mathrm{Hg}$ emissions in different regions of the Northern hemisphere (3- USSR, 4-Europe, 5U.S., 6-China and India). Data are plotted on a relative scale $(0-1)$. Gray arrow shows damming of Angara River and rise of $\sim 1.5 \mathrm{~m}$ in water level in L. Baikal.

U.S. occurred earlier than in the USSR, whereas Chinese and Indian $\mathrm{Hg}$ emissions follow a different trajectory than in other regions, continuing to increase in step with increasing use of coal there. ${ }^{9,46} \mathrm{Hg}$ emission estimates in different regions (Figure 5) can be combined with models of global atmospheric $\mathrm{Hg}$ transport $^{73}$ to evaluate the potential of different regions to serve as sources of $\mathrm{Hg}$ to Lake Baikal. The southern and central portions of L. Baikal are downwind from the Angara River Industrial Corridor, which has been shown to contribute heavy metals and organic pollutants to the region..$^{10,47,74}$ The Irkutsk region experienced rapid, coal-fueled industrialization in the 1940 s and 1950s, with additional manufacturing spurred by the construction of massive hydroelectric dams along the Angara River in the 1960 s and 1970s. ${ }^{10,75}$ The decline of Soviet industry starting in the 1980s affected energy consumption and $\mathrm{Hg}$ emissions in the Irkutsk region and the rest of the USSR (Figure 5). ${ }^{12,46,75}$ Interestingly, declines in $\mathrm{Hg}$ and $\mathrm{Cd}$ levels in seal dentine appear to predate decline in coal consumption and heat capacity in the Irkutsk region (Figure 5). It is possible that improved efficiency and pollution controls in Soviet power plants in the 1970s and 1980s helped reduce regional $\mathrm{Hg}$ and Cd inputs. Another possibility is that European emissions, which started declining earlier than Soviet emissions, contributed significant amounts of $\mathrm{Hg}$ and $\mathrm{Cd}$ to Lake Baikal. North American and Asian sources do not appear to drive patterns of $\mathrm{Hg}$ in the Baikal seal; the former probably due to distance, the latter due to being downstream of main atmospheric transport pathways. ${ }^{73}$ Another possible source of metals to Lake Baikal is the massive shoreline erosion that occurred in the late 1950 s following a $\sim 1.5 \mathrm{~m}$ water level increase due to the damming of the Angara River for the construction of the Irkutsk hydroelectric power plant. Although the increase in $\mathrm{Hg}$ and some other metals in seal dentine matches the timing of the dam construction, it is difficult to evaluate the importance of this source relative to others with our data.

We have shown that $\mathrm{Hg}$ and $\mathrm{Cd}$ levels in Baikal seals decreased since peaking in the 1960s and 1970s, suggesting that despite the size and remoteness of Lake Baikal, metal levels in its food web respond rapidly to changing inputs. Projected stabilization in use of coal power in potential source regions of 
$\mathrm{Hg}$ to Lake Baikal $^{76}$ may mean that $\mathrm{Hg}$ inputs will stabilize as well. However, increased mining and industrial development in the watershed and airshed or changes to the hydrological regime and food web structure may lead to changing levels of heavy metals in the Baikal food web. Long-term monitoring of inputs and concentrations of metals and other contaminants in different compartments of the Baikal ecosystem is needed to ensure protection of this unique lake.

\section{ASSOCIATED CONTENT}

\section{S Supporting Information}

The Supporting Information is available free of charge on the ACS Publications website at DOI: 10.1021/acs.est.7b00995.

Table S1: LA-ICP-MS run parameters Figure S1: Map of Lake Baikal and major settlements. Inset photo of Baikal seals in northern L. Baikal in August, 2014. Figure S2: Scatterplot matrix showing relationships between standardized metal $/{ }^{48} \mathrm{Ca}$ ratios of different metals in Baikal seal teeth. Spearman's rho and p-values for correlations are shown in the upper right portion of the figure (PDF)

\section{AUTHOR INFORMATION}

\section{Corresponding Author}

*E-mail: tozersky@d.umn.edu.

\section{ORCID}

Ted Ozersky: 0000-0002-1842-7745

\section{Notes}

The authors declare no competing financial interest.

\section{ACKNOWLEDGMENTS}

The pioneering research and scientific collections of Baikal seals conducted by Vladimir Pastukhov made this study possible and warrant special recognition. We thank Kate Corcoran, Abby Duck, Jenna Disch, Graham Durovich, Amanda Gardner, Gabi Guzman, Julia Halbur, Diana Lee, Iris Lin, Kirill Shchapov, and Melaina Wright for help with sample processing and analysis. We acknowledge the use of the NSF-supported WHOI ICPMS facility and thank Scott Birdwhistle for his assistance. We also thank David Hawkins, Steve Katz and Simon Thorrold for help and suggestions on sample processing, data and LA-ICP-MS analyses. Comments by three anonymous reviewers helped to substantially improve this manuscript. This work was supported by a Brachman-Hoffman Fellowship, a Brachman-Hoffman Small Grant, and a Fiske grant from Wellesley College in addition to the Dimensions of Biodiversity Program of the US National Science Foundation (DEB-1136657).

\section{REFERENCES}

(1) Nriagu, J. O. A history of global metal pollution. Science 1996, 272 (5259), 223.

(2) Hylander, L. D.; Meili, M. 500 years of mercury production: global annual inventory by region until 2000 and associated emissions. Sci. Total Environ. 2003, 304 (1), 13-27.

(3) Callender, E., 2003. Heavy metals in the environment historical trends. In: Environmental Geochemistry. Treatise on Geochemistry 9; Lollar, B. S., Ed; Elsevier: Oxford, 2003; pp 67-105.

(4) Nriagu, J. O. A silent epidemic of environmental metal poisoning? Environ. Pollut. 1988, 50 (1), 139-161.

(5) Järup, L. Hazards of heavy metal contamination. British Medical Bulletin 2003, 68 (1), 167-182.

(6) Candelone, J. P.; Hong, S.; Pellone, C.; Boutron, C. F. PostIndustrial Revolution changes in large-scale atmospheric pollution of the northern hemisphere by heavy metals as documented in central
Greenland snow and ice. J. Geophys. Res. 1995, 100 (D8), 1660516616.

(7) Fitzgerald, W. F.; Engstrom, D. R.; Mason, R. P.; Nater, E. A. The case for atmospheric mercury contamination in remote areas. Environ. Sci. Technol. 1998, 32 (1), 1-7.

(8) McConnell, J. R.; Edwards, R. Coal burning leaves toxic heavy metal legacy in the Arctic. Proc. Natl. Acad. Sci. U. S. A. 2008, 105 (34), 12140-12144.

(9) Kang, S.; Huang, J.; Wang, F.; Zhang, Q.; Zhang, Y.; Li, C.; Sillanpää, M. Atmospheric Mercury Depositional Chronology Reconstructed from Lake Sediments and Ice Core in the Himalayas and Tibetan Plateau. Environ. Sci. Technol. 2016, 50 (6), 2859-2869.

(10) Boyle, J. F.; Mackay, A. W.; Rose, N. L.; Flower, R. J.; Appleby, P. G. Sediment heavy metal record in Lake Baikal: natural and antrhopogenic sources. Journal of Paleolimnology 1998, 20 (2), 135150.

(11) Eichler, A.; Tobler, L.; Eyrikh, S.; Gramlich, G.; Malygina, N.; Papina, T.; Schwikowski, M. Three centuries of Eastern European and Altai lead emissions recorded in a Belukha ice core. Environ. Sci. Technol. 2012, 46 (8), 4323-4330.

(12) Eichler, A.; Tobler, L.; Eyrikh, S.; Malygina, N.; Papina, T.; Schwikowski, M. Ice-core based assessment of historical anthropogenic heavy metal $(\mathrm{Cd}, \mathrm{Cu}, \mathrm{Sb}, \mathrm{Zn})$ emissions in the Soviet Union. Environ. Sci. Technol. 2014, 48 (5), 2635-2642.

(13) Hong, S.; Soyol-Erdene, T. O.; Hwang, H. J.; Hong, S. B.; Hur, S. D.; Motoyama, H. Evidence of global-scale As, Mo, Sb, and Tl atmospheric pollution in the Antarctic snow. Environ. Sci. Technol. 2012, 46 (21), 11550-11557.

(14) Krause-Nehring, J.; Brey, T.; Thorrold, S. R. Centennial records of lead contamination in northern Atlantic bivalves (Arctica islandica). Mar. Pollut. Bull. 2012, 64 (2), 233-240.

(15) Berg, W.; Johnels, A.; Sjöstrand, B.; Westermark, T. Mercury content in feathers of Swedish birds from the past 100 years. Oikos 1966, 17, 71-83.

(16) Evans, R. D.; Richner, P.; Outridge, P. M. Micro-spatial variations of heavy metals in the teeth of walrus as determined by laser ablation ICP-MS: the potential for reconstructing a history of metal exposure. Arch. Environ. Contam. Toxicol. 1995, 28 (1), 55-60.

(17) Dietz, R.; Born, E. W.; Riget, F.; Aubail, A.; Sonne, C.; Drimmie, $\mathrm{R}$; Basu, N. Temporal trends and future predictions of mercury concentrations in Northwest Greenland polar bear (Ursus maritimus) hair. Environ. Sci. Technol. 2011, 45 (4), 1458-1465.

(18) Farell, J.; Amarasiriwardena, D.; Goodman, A. H.; Arriaza, B. Bioimaging of trace metals in ancient Chilean mummies and contemporary Egyptian teeth by laser ablation-inductively coupled plasma-mass spectrometry (LA-ICP-MS). Microchem. J. 2013, 106, 340-346.

(19) Poste, A. E.; Muir, D. C.; Guildford, S. J.; Hecky, R. E. Bioaccumulation and biomagnification of mercury in African lakes: The importance of trophic status. Sci. Total Environ. 2015, 506, 126136.

(20) Aubail, A.; Dietz, R.; Rigét, F.; Sonne, C.; Wiig, Ø.; Caurant, F. Temporal trend of mercury in polar bears (Ursus maritimus) from Svalbard using teeth as a biomonitoring tissue. J. Environ. Monit. 2012, 14 (1), 56-63.

(21) Poste, A. E.; Pastukhov, M. V.; Braaten, H. F. V.; Ozersky, T.; Moore, M. V. Seal teeth document the rise and fall of mercury contamination in the food web of Lake Baikal. Sci. Total Environ.; In review.

(22) Nomokonova, T.; Losey, R. J.; Iakunaeva, V. N.; Emel'ianova, I. A.; Baginova, E. A.; Pastukhov, M. V. People and seals at Siberia's Lake Baikal. Journal of Ethnobiology 2013, 33 (2), 259-280.

(23) Watanabe, I.; Ichihashi, H.; Tanabe, S.; Amano, M.; Miyazaki, N.; Petrov, E. A.; Tatsukawa, R. Trace element accumulation in Baikal seal (Phoca sibirica) from the Lake Baikal. Environ. Pollut. 1996, 94 (2), 169-179.

(24) Ciesielski, T.; Pastukhov, M. V.; Szefer, P.; Jenssen, B. M. Bioaccumulation of mercury in the pelagic food chain of the Lake Baikal. Chemosphere 2010, 78 (11), 1378-1384. 
(25) $\mathrm{Li}$, J. Distribution and maternal transfer of arsenic, cadmium, mercury, lead and selenium in Baikal seals (Phoca sibirica). Master's thesis, Norwegian University of Science and Technology, May 2013.

(26) Ponomarev, E. I.; Kharuk, V. I.; Ranson, K. J. Wildfires Dynamics in Siberian Larch Forests. Forests 2016, 7 (6), 125.

(27) Kaus, A.; Schäffer, M.; Karthe, D.; Büttner, O.; von Tümpling, W.; Borchardt, D. Regional patterns of heavy metal exposure and contamination in the fish fauna of the Kharaa River basin (Mongolia). Regional Environmental Change 2016, DOI: 10.1007/s10113-0160969-4.

(28) Timoshkin, O. A.; Samsonov, D. P.; Yamamuro, M.; Moore, M. V.; Belykh, O. I.; Malnik, V. V.; Fedorova, G. A. Rapid ecological change in the coastal zone of Lake Baikal (East Siberia): Is the site of the world's greatest freshwater biodiversity in danger? Journal of Great Lakes Research 2016, 42 (3), 487-497.

(29) Izmest'eva, L. R.; Moore, M. V.; Hampton, S. E.; Ferwerda, C. J.; Gray, D. K.; Woo, K. H.; Silow, E. A. Lake-wide physical and biological trends associated with warming in Lake Baikal. J. Great Lakes Res. 2016, 42 (1), 6-17.

(30) Pastukhov, V. D. Nerpa Baikala [The Baikal Seal]. Novosibirsk: Nauka, 1993 (In Russian).

(31) Weber, A.; Goriunova, O. I.; Konopatskii, A. K. Prehistoric seal hunting on Lake Baikal: methodology and preliminary results of the analysis of canine sections. Journal of Archaeological Science 1993, 20 (6), 629-644.

(32) Stern, R. A.; Outridge, P. M.; Davis, W. J.; Stewart, R. E. A. Reconstructing lead isotope exposure histories preserved in the growth layers of walrus teeth using the SHRIMP II ion microprobe. Environ. Sci. Technol. 1999, 33 (10), 1771-1775.

(33) Outridge, P. M.; Wagemann, R; McNeely, R. Teeth as biomonitors of soft tissue mercury concentrations in beluga. Environ. Toxicol. Chem. 2000, 19 (6), 1517-1522.

(34) Koch, P. L. Isotopic study of the biology of modern and fossil vertebrates. In Stable Isotopes in Ecology and Environmental Science, 2nd ed.; Michener, R.; Lajtha, K., Eds.; Blackwell Publishing: Boston, 2007; pp 99-154.

(35) Newsome, S. D.; Etnier, M. A.; Kurle, C. M.; Waldbauer, J. R.; Chamberlain, C. P.; Koch, P. L. Historic decline in primary productivity in western Gulf of Alaska and eastern Bering Sea: isotopic analysis of northern fur seal teeth. Mar. Ecol.: Prog. Ser. 2007, $332,211-224$

(36) Hanson, N.; Jones, E. L.; Harris, R. N. Multi-decadal and ontogenetic trophic shifts inferred from stable isotope ratios of pinniped teeth. Oikos 2017, DOI: 10.1111/oik.04441.

(37) Ogawa, N. O.; Yoshii, K.; Melnik, N. G.; Bondarenko, N. A.; Timoshkin, O. A.; Zalumi, N. S.; Smirnov, V. V.; Wada, E. Carbon and nitrogen isotope studies of the pelagic ecosystem and environmental fluctuations of Lake Baikal. In Lake Baika, A Mirror in Time and Space for Understanding Global Change Processes; Minoura, K., Ed.; Elsevier Science: Amsterdam, 2000; pp 262-272.

(38) Rohatgi, A. WebPlotDigitizer 2011. URL http://arohatgi.info/ WebPlotDigitizer/app.

(39) Verburg, P. The need to correct for the Suess effect in the application of $\delta 13 \mathrm{C}$ in sediment of autotrophic Lake Tanganyika, as a productivity proxy in the Anthropocene. Journal of Paleolimnology 2007, 37 (4), 591-602.

(40) Ben-Tzvi, O.; Abelson, A.; Gaines, S. D.; Sheehy, M. S.; Paradis, G. L.; Kiflawi, M. The inclusion of sub-detection limit LA-ICPMS data, in the analysis of otolith microchemistry, by use of a palindrome sequence analysis (PaSA). Limnol. Oceanogr.: Methods 2007, 5 (3), 97-105.

(41) Wood, S.; Wood, M. S. Package 'mgcv'. $R$ package version, 1-7 2016.

(42) RDC Team R: A language and environment for statistical computing 2015.

(43) Zuur, A. F.; Ieno, E. N.; Walker, N. J.; Saveliev, A. A.; Smith, G. M. Mixed Effects Models and Extensions in Ecology with R; Springer Science and Business Media: New York, 2009.
(44) Pinheiro, J.; Bates, D.; DebRoy, S.; Sarkar, D. nlme: linear and nonlinear mixed effects models. R package version 3.1-117 2014.

(45) Hothorn, T.; Bretz, F.; Westfall, P.; Heiberger, R. M. Multcomp: Simultaneous Inference in General Parametric Models- $\mathrm{R}$ Package Version 1.0-0 2008.

(46) Streets, D. G.; Devane, M. K.; Lu, Z.; Bond, T. C.; Sunderland, E. M.; Jacob, D. J. All-time releases of mercury to the atmosphere from human activities. Environ. Sci. Technol. 2011, 45 (24), 10485-10491.

(47) Rose, N. L.; Appleby, P. G.; Boyle, J. F.; Mackay, A. W.; Flower, R. J. The spatial and temporal distribution of fossil-fuel derived pollutants in the sediment record of Lake Baikal, east Siberia. Journal of Paleolimnology 1998, 20 (2), 151-162.

(48) Gu, B.; Schelske, C. L.; Brenner, M. Relationship between sediment and plankton isotope ratios $\left(\delta^{13} \mathrm{C}\right.$ and $\left.\delta^{15} \mathrm{~N}\right)$ and primary productivity in Florida lakes. Can. J. Fish. Aquat. Sci. 1996, 53 (4), $875-883$.

(49) Poste, A. E.; Hecky, R. E.; Guildford, S. J. Phosphorus enrichment and carbon depletion contribute to high Microcystis biomass and microcystin concentrations in Ugandan lakes. Limnol. Oceanogr. 2013, 58 (3), 1075-1088.

(50) Hampton, S. E.; Izmest'eva, L. R.; Moore, M. V.; Katz, S. L.; Dennis, B.; Silow, E. A. Sixty years of environmental change in the world's largest freshwater lake-Lake Baikal, Siberia. Global Change Biology 2008, 14 (8), 1947-1958.

(51) Hecky, R. E.; Hesslein, R. H. Contributions of benthic algae to lake food webs as revealed by stable isotope analysis. Journal of the North American Benthological Society 1995, 14 (4), 631-653.

(52) Minagawa, M.; Wada, E. Stepwise enrichment of $15 \mathrm{~N}$ along food chains: further evidence and the relation between $\delta 15 \mathrm{~N}$ and animal age. Geochim. Cosmochim. Acta 1984, 48 (5), 1135-1140.

(53) Holtgrieve, G. W.; Schindler, D. E.; Hobbs, W. O.; Leavitt, P. R.; Ward, E. J.; Bunting, L.; Lisac, M. J. A coherent signature of anthropogenic nitrogen deposition to remote watersheds of the northern hemisphere. Science 2011, 334 (6062), 1545-1548.

(54) Lochner, F.; Appleton, J.; Keenan, F.; Cooke, M. Multi-element profiling of human deciduous teeth by laser ablation-inductively coupled plasma-mass spectrometry. Anal. Chim. Acta 1999, 401 (1), 299-306.

(55) Kang, D.; Amarasiriwardena, D.; Goodman, A. H. Application of laser ablation-inductively coupled plasma-mass spectrometry (LAICP-MS) to investigate trace metal spatial distributions in human tooth enamel and dentine growth layers and pulp. Anal. Bioanal. Chem. 2004, 378 (6), 1608-1615.

(56) Stadlbauer, C.; Reiter, C.; Patzak, B.; Stingeder, G.; Prohaska, T. History of individuals of the 18th/19th centuries stored in bones, teeth, and hair analyzed by LA-ICP-MS-a step in attempts to confirm the authenticity of Mozart's skull. Anal. Bioanal. Chem. 2007, 388 (3), 593-602.

(57) Galiová, M. V.; Fišáková, M. N.; Kynický, J.; Prokeš, L.; Neff, H.; Mason, A. Z.; Kanický, V. Elemental mapping in fossil tooth root section of Ursus arctos by laser ablation inductively coupled plasma mass spectrometry (LA-ICP-MS). Talanta 2013, 105, 235-243.

(58) Wagemann, R.; Stewart, R. E. A.; Lockhart, W. L.; Stewart, B. E.; Povoledo, M. Trace metals and methyl mercury: associations and transfer in harp seal (Phoca groenlandica) mothers and their pups. Mar. Mammal Sci. 1988, 4 (4), 339-355.

(59) Castellini, J. M.; Rea, L. D.; Lieske, C. L.; Beckmen, K. B.; Fadely, B. S.; Maniscalco, J. M.; O’Hara, T. M. Mercury concentrations in hair from neonatal and juvenile Steller sea lions (Eumetopias jubatus): Implications based on age and region in this Northern Pacific marine sentinel piscivore. EcoHealth 2012, 9 (3), 267-277.

(60) Aylward, L. L.; Hays, S. M.; Kirman, C. R.; Marchitti, S. A.; Kenneke, J. F.; English, C.; Becker, R. A. Relationships of chemical concentrations in maternal and cord blood: a review of available data. J. Toxicol. Environ. Health, Part B 2014, 17 (3), 175-203.

(61) Gibson, J. E.; Becker, B. A. Placental transfer, embryotoxicity, and teratogenicity of thallium sulfate in normal and potassiumdeficient rats. Toxicol. Appl. Pharmacol. 1970, 16 (1), 120-132. 
(62) Sikov, M. R.; Mahlum, D. D. Cross-placental transfer of selected actinides in the rat. Health Phys. 1968, 14 (3), 205-208.

(63) Edel, J.; Sabbioni, E. Vanadium transport across placenta and milk of rats to the fetus and newborn. Biol. Trace Elem. Res. 1989, 22 (3), 265-275.

(64) Bremner, I.; Davies, N. T. The induction of metallothionein in rat liver by zinc injection and restriction of food intake. Biochem. J. 1975, 149 (3), 733-738.

(65) Richards, M. P.; Rosebrough, R. W.; Steele, N. C. Effects of starvation and refeeding on tissue zinc, copper and iron in turkey poults. J. Nutr. 1987, 117, 481-489.

(66) Laskowski, R. Are the top carnivores endangered by heavy metal biomagnification? Oikos 1991, 60, 387-390.

(67) Croteau, M. N.; Luoma, S. N.; Stewart, A. R. Trophic transfer of metals along freshwater food webs: evidence of cadmium biomagnification in nature. Limnol. Oceanogr. 2005, 50 (5), 1511-1519.

(68) Engstrom, D. R.; Swain, E. B. Recent declines in atmospheric mercury deposition in the upper Midwest. Environ. Sci. Technol. 1997, 31 (4), 960-967.

(69) Schuster, P. F.; Krabbenhoft, D. P.; Naftz, D. L.; Cecil, L. D.; Olson, M. L.; Dewild, J. F.; Abbott, M. L. Atmospheric mercury deposition during the last 270 years: a glacial ice core record of natural and anthropogenic sources. Environ. Sci. Technol. 2002, 36 (11), 2303-2310.

(70) Yang, H.; Rose, N. L. Distribution of mercury in six lake sediment cores across the UK. Sci. Total Environ. 2003, 304 (1), 391404.

(71) Yang, H.; Battarbee, R. W.; Turner, S. D.; Rose, N. L.; Derwent, R. G.; Wu, G.; Yang, R. Historical reconstruction of mercury pollution across the Tibetan Plateau using lake sediments. Environ. Sci. Technol. 2010, 44 (8), 2918-2924.

(72) Ratafia-Brown, J. A. Overview of trace element partitioning in flames and furnaces of utility coal-fired boilers. Fuel Process. Technol. 1994, 39 (1-3), 139-157.

(73) Corbitt, E. S.; Jacob, D. J.; Holmes, C. D.; Streets, D. G.; Sunderland, E. M. Global source-receptor relationships for mercury deposition under present-day and 2050 emissions scenarios. Environ. Sci. Technol. 2011, 45 (24), 10477-10484.

(74) Mamontov, A. A.; Mamontova, E. A.; Tarasova, E. N.; McLachlan, M. S. Tracing the sources of PCDD/Fs and PCBs to Lake Baikal. Environ. Sci. Technol. 2000, 34 (5), 741-747.

(75) Tarakanov, M. A. Promyslinost' Irkutskoj Oblasti [Industry of the Irkutsk Region]; Irkutsk University Press: Irkutsk, 2001 (In Russian).

(76) USEIA. International energy outlook 2016; U.S. Energy Information Administration (EIA), 2016. 